Mursalov M. M., Ph.D. (Economics)

Azerbaijan State University of Economics (UNEC)

Baku, Azerbaijan

DOI: https://doi.org/10.30525/978-9934-26-064-3-36

\title{
ACTUAL PROBLEMS OF FORMATION FINANCIAL MARKET MEGA-REGULATOR
}

Since February 2016, the financial sector of Azerbaijan, due to the emergence of a single mega-regulator, began to work in a new reality. This event was controversial, and discussions were held on the creation of a mega-regulator. Moreover, practically from the very first steps of its existence, this institution faced unexpected challenges associated with a new wave of the economic crisis and price instability of the global energy market. In the current conditions, an in-depth analysis of mega-regulation is of particular relevance.

The modern period is characterized by a dynamic change in the financial markets. In the context of globalization, any imbalance in any sector of this market can cause unforeseen difficulties, including economic collapse. In this regard, financial markets feel an urgent need for an effective model of regulation and supervision. In many states, this leads to active reforms in the respective systems. In world practice, depending on the goals and objects of regulation, there are four models of integration of financial regulation and supervision:

- Consolidated model: one mega-regulator; full integration, i.e. the state gives one body the powers of microprudential regulation and supervision of all types of financial institutions and financial markets (Canada, Germany, Denmark, Russia, Azerbaijan).

- "Twin peaks" model: two bodies with different goals; partial sectoral integration, i.e. each body is responsible for at least two types 
of financial intermediaries from several major ones (Great Britain, Austria, Luxembourg).

- Hybrid model: separate regulator for each type of business; there is no sectoral integration; regulation and supervision of the salary activities of key types of financial intermediaries are in charge of specialized agencies (USA, France, Brazil).

- Institutional model: self-regulatory organizations (China, Mexico).

From the point of view of the current macroeconomic conditions, the creation of a mega-regulator of financial markets is considered the most adequate system of control and regulation. The transition to such an integrated system (mega-regulation) is the main international trend in recent years in the field of financial regulation $[1$, p. $5 ; 2$, p. 225; 3 ; 4, p. 63]. Currently, mega-regulators operate in more than 160 countries around the world. Norway and Singapore were the first to establish such an institution (in 1986 and 1987, respectively). Then they appeared in other countries, for example, in Iceland and Denmark in 1988, Sweden - in 1991, Great Britain - in 1998, Germany - in 2002, Russia - in 2013 [5, p. 249], Azerbaijan - in 2016 [6, p. 249]. The main reasons for the transition to consolidated regulation and the formation of mega-regulators of financial markets in modern conditions are reflected in Table 1.

In Azerbaijan, by the end of 2019, regulatory functions in the monetary system were divided between the Central Bank (hereinafter the Central Bank) and the newly created regulatory body the Chamber for Control over Financial Markets (hereinafter the Chamber). At the same time, the Central Bank carried out monetary policy, and the Chamber was empowered to regulate and supervise financial markets and, in fact, ensured their effective activity as a mega-regulator. If the Central Bank had many years of significant experience in the country's banking market, then the Chamber, created by the Decree of the President of Azerbaijan on March 16, 2016 and covering such financial segments of the economy as the securities market, investment funds, insurance, credit organizations (banks, nonbank credit organizations and a postal operator), was at the initial 
stage of its formation and development. After almost 4 years, the activities of the Chamber were found unsatisfactory, it was liquidated, and its powers were transferred to the Central Bank.

Table 1

\section{The main reasons for the transition to the model of a single regulator}

\begin{tabular}{|c|c|}
\hline $\begin{array}{c}\text { Active formation } \\
\text { of financial conglomerates }\end{array}$ & $\begin{array}{l}\text { The need to reduce the level } \\
\text { of systemic risks in general }\end{array}$ \\
\hline $\begin{array}{l}\text { Widespread diversification of products } \\
\text { and services provided by financial } \\
\text { and credit institutions to their clients }\end{array}$ & $\begin{array}{l}\text { The need to unify the standards } \\
\text { for the activities of financial } \\
\text { intermediaries in certain areas } \\
\text { of activity in the financial market }\end{array}$ \\
\hline $\begin{array}{c}\text { Surge expansion of opportunities } \\
\text { for transferring risks between various } \\
\text { sectors of the financial market, including } \\
\text { through the spread of financial innovations } \\
\text { and the development of new sectors } \\
\text { of the financial market }\end{array}$ & $\begin{array}{l}\text { Convergence of principles } \\
\text { and standards of regulation in } \\
\text { different sectors of the financial } \\
\text { market on a global scale, leading } \\
\text { to the unification of goals, } \\
\text { objectives and mechanisms of } \\
\text { regulation, supervision and control }\end{array}$ \\
\hline $\begin{array}{l}\text { Seeking to reduce regulatory costs through } \\
\text { economies of scale and concentration } \\
\text { of resources in the most critical areas }\end{array}$ & $\begin{array}{c}\text { Ensuring adequate financial } \\
\text { stability and the required level } \\
\text { of immunity in relation to the crisis } \\
\text { in the global capital market }\end{array}$ \\
\hline $\begin{array}{l}\text { The absence of a ban on the participation } \\
\text { of credit institutions in transactions with } \\
\text { securities and other high-risk financial } \\
\text { instruments in an environment where banks } \\
\text { are often the main carriers of risks } \\
\text { of a different nature and their translators } \\
\text { between different sectors } \\
\text { of the financial market }\end{array}$ & $\begin{array}{l}\text { The absence of a ban on the } \\
\text { participation of credit institutions } \\
\text { in transactions with securities and } \\
\text { other high-risk financial instru- } \\
\text { ments in an environment where } \\
\text { banks are often the main carriers } \\
\text { of risks of a different nature and } \\
\text { their translators between different } \\
\text { sectors of the financial market }\end{array}$ \\
\hline $\begin{array}{l}\text { The need to conduct a systemic policy for } \\
\text { the development of all sectors of the } \\
\text { national financial market in the context of a } \\
\text { significant intensification of cross-border } \\
\text { competition in this sector, gravitation } \\
\text { towards the transfer of operations to } \\
\text { international financial centers }\end{array}$ & $\begin{array}{l}\text { The need to ensure comprehensive } \\
\text { and uniform protection of the } \\
\text { interests of investors in all sectors } \\
\text { of the financial market in the face } \\
\text { of increasing complexity } \\
\text { of financial products }\end{array}$ \\
\hline
\end{tabular}

Source: compiled by the author based on $[6 ; 7 ; 8 ; 9 ; 10 ; 11]$ 
In our opinion, the following should be considered as the main directions for improving the mega-regulator:

- conducting regular monitoring and setting parameters for assessing the state of the financial sectors;

- assessing the mutual influence of financial sectors on each other;

- identification of synergy prospects, definition and assessment of control parameters;

- expanding the scope of application of modern financial technologies in the implementation of regulation and supervision, risk analysis, etc.;

- in addition to developing short-term and long-term plans for the development of financial sectors, regularly adjust them in accordance with the current state;

- improvement of the legal framework in order to eliminate legal gaps.

The priority task of the Central Bank is to increase the efficiency and timeliness of the supervisory response, to ensure preventive measures of supervision. The ability to identify problems of financial institutions at an early stage will reduce the frequency of revision of regulatory parameters and reduce the regulatory burden on bona fide market participants. In order to implement the regulatory measures of the Central Bank, it is necessary to expand the application in the supervisory process of assessing the quality of the bank's management and the nature of the decisions it makes. This will make it possible to prevent risks by identifying such features of corporate governance that negatively affect the activities of a credit institution. Work is needed to further develop stress testing. This requires the creation of an integrated analytical system built into the overall supervisory process, which would allow making decisions based on an independent operational analysis of banks' resilience to crisis situations at all levels.

Problems associated with the coronavirus pandemic do not allow making unambiguous conclusions regarding the effectiveness of financial market regulation. Due to the uncertainty of the development of the situation, the way out of it will be carried out for a long time. 
All expert assessments are currently predictive in nature, so the problem of the effectiveness of financial regulation will require further research and development. Work on the institute of a mega-regulator in Azerbaijan should continue, it is necessary to gradually introduce various changes, incl. aimed at eliminating deficiencies.

\section{References:}

1. Briault C. (2002) Revisiting the Rationale for a Single National Financial Services Regulator. Financial Services Authority Occasional Paper. No. 16. February, 40 p. DOI:10.2139/ssrn.427583

2. Kremers J.J.M., Shoenmaker D., Wierts P.J. (2003) Cross-Sector Supervision: Which Model? / Brookings-Wharton Papers on Financial Services / Ed. by R. Herring, R. Litan. Washington. P. 225-243. DOI:10.1353/pfs.2003.0004

3. Round table: A new model of regulation of the Russian financial sector. The Journal of the New Economic Association. 2013. № 9. P. 82-98, 128-154. (in Russian)

4. Buklemishev O.V., Danilov Y.A., Kokorev R.A. (2015) Mega-Regulator as a Result of Evolution of Financial Regulation. Moscow University Economics Bulletin, no. 4, pp. 62-74. (in Russian)

5. Banks and banking business in the global economy / ed. G.S. Panova. Moscow: MGIMO-University. 2020. 879 p. (in Russian)

6. Banks and financial markets of the XXI century - development potential / ed. Yu.I. Novikova, N.P. Radkovskaya. St. Petersburg: Publishing house of St. Petersburg State University of Economics. 2016. 299 p. (in Russian)

7. Briault C. (2000) The rationale for a single national financial services regulator / Opportunities and Risks in Central European Finances. Washington: IBRD \& World Bank. P. 211-227.

8. Ferran E. (2003) Examining the United Kingdom's Experience in Adopting the Single Financial Regulator Model, 28. Brooklyn Journal of International Law. Vol. 28, no. 2, pp. 257-307. Available at: https://brooklynworks.brooklaw.edu/bjil/ vol28/iss $2 / 2$

9. Brown E.F. (2005) E Pluribus Unum-Out of Many, One: Why the United States Needs a Single Financial Services Agency. University of Miami Business Law Review, vol. 14, no. 1, pp. 1-101. Available at: http://repository.law.miami.edu/ umblr/vol14/iss1/2

10. Yokoi-Arai M. (2006) The Regulatory Efficiency of a Single Regulator in Financial Services: Analysis of the UK and Japan. Banking \& Finance Law Review. October. No. 1, pp. 23-76.

1. Muscat M. (2019) Legitimacy of the Maltese Financial Services Regulator (Doctoral thesis). Cambridge: University of Cambridge. vii, 324 p. DOI:10.17863/ CAM.55873 